\title{
Effect of Chromium Content on Creep Rupture Properties of a High Chromium Ferritic Heat Resisting Steel
}

\author{
Xing Yang LIU1) and Toshio FUJITA2) \\ 1) Graduate Student, The University of Tokyo. Now at Northeast University of Technology, Shengyang, China. \\ Emeritus, The University of Tokyo, Hongo, Bunkyo-ku, Tokyo, 113 Japan.
}

2) Professor

(Received on September 2, 1988; accepted in the final form on March 10, 1989)

\begin{abstract}
The effect of chromium content in the range of 10 to $13 \%$ on the mechanical properties has been investigated of a heat resisting steel for turbine rotors. It is revealed that increase in chromium content brings about increased amounts of dissolved chromium and the $\mathrm{Cr}_{2}(\mathrm{C}, \mathrm{N})$ type carbides, both of which enhance room temperature and elevated-temperature strengths. However, excessive addition of chromium to about $13 \%$ results in the formation of delta-ferrite, which is detrimental to creep rupture strength, especially on the long-term side. Thus, the optimum chromium content is considered to be at around $11.5 \%$.
\end{abstract}

KEY WORDS: heat resisting steel; elevated-temperature strength; chromium content; dissolved chromium; $\mathrm{Cr}_{2}(\mathrm{C}, \mathrm{N})$ type carbides; delta-ferrite.

\section{Introduction}

Chromium is an essential element in heat resisting steels because it enhances resistance to oxidation and corrosion at elevated temperature. Chromium also has an important effect on toughness and elevated temperature strength. ${ }^{1-4}$ ) For rotor forgings, oxidation resistance and creep rupture strength are two of the main aspects of design considerations. In order to obtain sufficient oxidation and corrosion resistances at 600 to $650^{\circ} \mathrm{C}$ : the temperature range of the UltraSuper-Critical (USG) pressure steam turbine rotors, at least $9 \%$ chromium is supposed to be necessary. ${ }^{5,6)}$ On the other hand, when the strengths and fatigue properties are taken into account, the microstructure of the steels after quenching should be designed to be a single martensitic phase, i.e., free from delta-ferrite or retained austenite. From the $\mathrm{Fe}-\mathrm{Cr}-\mathrm{C}$ phase diagrams, ${ }^{7,8)}$ the maximum chromium content on the gamma loop of low-carbon chromium steels varies in the range of 11 to $14 \mathrm{wt} \%$, depending on the carbon content. This phase constitution, then, limits the maximum chromium content for the rotor forgings.

Some papers have already reported the effects of chromium content on crecp rupture strength and toughness at ambient temperature for low-carbon steels. ${ }^{1-3)}$ However, since the steels used in these studies contained either more ferrite-formers ${ }^{1,3)}$ or less carbon $^{1,2)}$ that certain amount of delta-ferrite tended to form when chromium content was beyond about $7 \mathrm{wt} \%$. Fujita et al. ${ }^{91}$ reported that creep rupture strength increased with chromium content in the range of 0 to $11 \mathrm{wt} \%$, but no detailed investigation into the effect of chromium content in the range of 10 to $13 \%$ was included. In order to optimize the chromium content of the high-chromium ferritic heat resisting steels for the USG turbine rotors, the effect of chromium content on the creep rupture properties was investigated in detail in this study.

\section{Experimental}

The compositions of the steels used are given in Table 1. The chromium content was varied from 10 to $13 \mathrm{wt} \%$ in a $0.13 \mathrm{C}-0.5 \mathrm{Mn}-0.8 \mathrm{Ni}-\mathrm{Cr}-0.5 \mathrm{Mo}-1.8$ $\mathrm{W}-0.2 \mathrm{~V}-0.05 \mathrm{Nb}-0.05 \mathrm{~N}$ steel. A $10 \mathrm{~kg}$ ingot for each steel was prepared by a vacuum induction melting furnace and forged to $40 \times 40 \times 400 \mathrm{~mm}$ bars. After being austenitized at $1020^{\circ} \mathrm{C}$ for $5 \mathrm{~h}$, the specimens were cooled down to $600^{\circ} \mathrm{C}$ with a cooling rate of $100^{\circ} \mathrm{C} / \mathrm{h}$, followed by cooling in air. Tempering was carried out at $710^{\circ} \mathrm{C}$ for $20 \mathrm{~h}$.

Round bar test pieces of $30 \mathrm{~mm}$ in gauge length and $6 \mathrm{~mm}$ in diameter were used for creep rupture as well as tensile tests, and standard V-notch specimens for a Charpy impact test.

The precipitates were electrolytically extracted from the as-normalized, as-tempered and crept speci-

Table 1. Chemical compositions. (wt\%)

\begin{tabular}{cccccccccccc} 
& $\mathrm{C}$ & $\mathrm{Si}$ & $\mathrm{Mn}$ & $\mathrm{Ni}$ & $\mathrm{Cr}$ & $\mathrm{Mo}$ & $\mathrm{W}$ & $\mathrm{V}$ & $\mathrm{Nb}$ & $\mathrm{N}$ \\
\hline $\mathrm{A}$ & 0.13 & 0.06 & 0.48 & 0.79 & 9.86 & 0.48 & 1.81 & 0.19 & 0.047 & 0.0628 \\
$\mathrm{~B}$ & 0.13 & 0.06 & 0.49 & 0.80 & 11.42 & 0.49 & 1.83 & 0.19 & 0.046 & 0.0586 \\
$\mathrm{C}$ & 0.13 & 0.06 & 0.47 & 0.79 & 12.86 & 0.48 & 1.81 & 0.19 & 0.045 & 0.0698 \\
\hline
\end{tabular}


mens. The residues were collected on paper filters with pores of $0.2 \mu \mathrm{m}$ in diameter, and identified by X-ray diffraction with the use of $K \alpha$ radiation of $\mathrm{Cu}$. The compositions of the collected residues were analyzed by an energy dispersion X-ray analyzer (EDXA). The analyzed area on filter was about $1 \times 1 \mathrm{~mm}$. The amount of each alloying element in precipitates was obtained by multiplying the amount of residues with the concentration of the element in residues.

The microstructure was investigated by an optical and a transmission electron microscope.

\section{Results}

\subsection{Creep Ruplure Properties}

Creep rupture curves for steels $A, B$ and $C$ are shown in Fig. 1. At both 650 and $700^{\circ} \mathrm{C}$, increasing chromium content from 10 to $11.5 \mathrm{wt} \%$ improves creep rupture strength. However, further increase in chromium content to $13 \mathrm{wt} \%$ has a reverse effect on the rupture strength at the lower stress levels.

Fig. 2 shows the master rupture curves for the three steels, with the Larson-Miller's parameter $\mathbf{C}$ being selected to be 40 . From the figure, the extrapolated creep rupture strength for $10^{5} \mathrm{~h}$ at $600^{\circ} \mathrm{G}$ is about $18 \mathrm{kgf} / \mathrm{mm}^{2}$, and that at $650^{\circ} \mathrm{C}$ is about 10 $\mathrm{kgf} / \mathrm{mm}^{2}$ for steel $\mathrm{B}$, the strongest one among the three steels. These values are much higher than those of the conventional super $12 \% \mathrm{Cr}$ heat resisting steels ${ }^{10}$ ) and show a possibility for the steel to be employed at the temperatures up to $621^{\circ} \mathrm{C}$.

Greep rupture ductilities are shown in Fig. 3. Neither apparent difference among the three steels nor serious decrease in creep rupture ductilities was

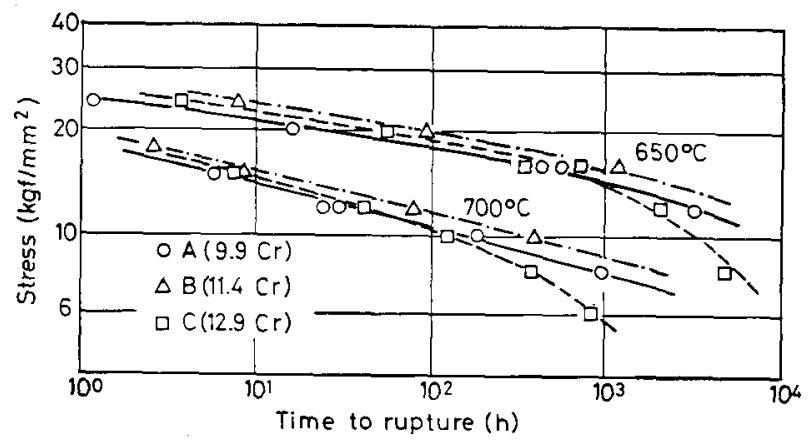

Fig. 1. Creep rupture curves at 650 and $700^{\circ} \mathrm{C}$.

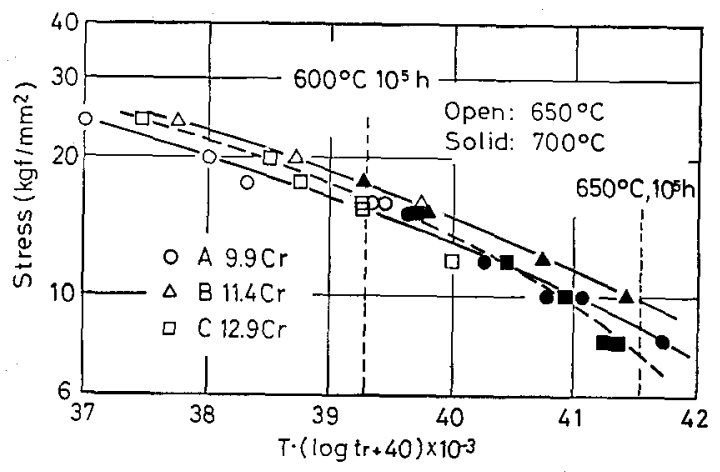

Fig. 2. Master rupture curves. observed with rupture time up to about $10^{4} \mathrm{~h}$.

\subsection{Toughness and Tensile Properties}

Change of Charpy absorbed energy with chromium content in the as-tempered condition is shown in Fig. 4. The Charpy absorbed energy decreases with the increase of chromium content, and show a shapr decrease when chromium content is beyond $11.4 \%$. From the fact that the absorbed energy at $0^{\circ} \mathrm{C}$ is approximately equal to that at $20^{\circ} \mathrm{C}$ for each steel, it can be deduced that the ductile to brittle transition temperatures (DBTT) are lower than $0^{\circ} \mathrm{C}$ for steels $\mathrm{A}$ and $\mathrm{B}$, and the DBTT is higher than $20^{\circ} \mathrm{C}$ for steel C. The results indicate that increasing chromium content to more than $11.4 \%$ could be very detrimental to room temperature toughness.

Tensile properties at room temperature are shown in Fig. 5. Increasing in chromium content results in

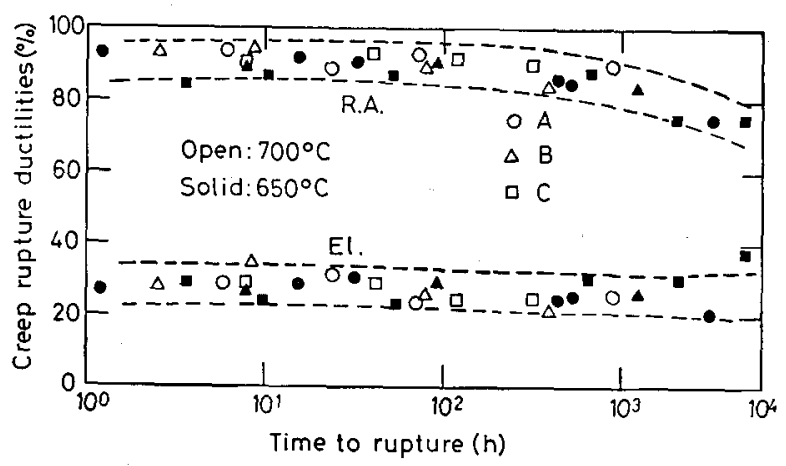

Fig. 3. Creep rupture ductilities.

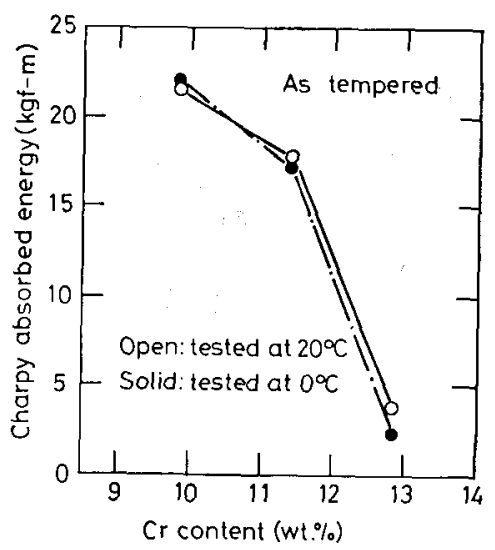

Fig. 4. Effect of chromium content on impact toughness.

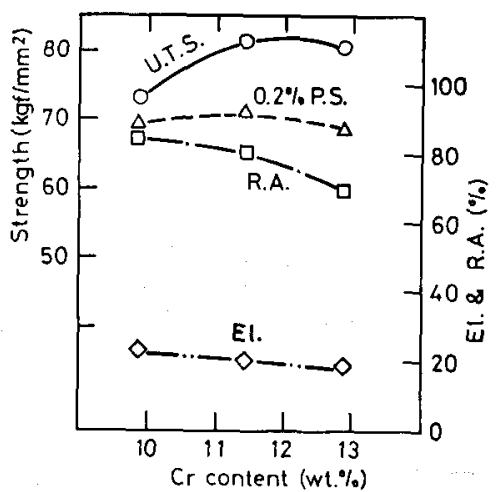

Fig. 5. Effect of chromium content on tensile properties at room temperature. 
a slight increase in ultimate tensile strength and a decrease in reduction of area, but has little effect on $0.2 \%$ proof stress and elongation.

\subsection{Microstructure}

In the as-normalized condition, the microstructures of steels A and B consist of a single martensite phase. In contrast, steel $\mathrm{C}$ contains about $2 \%$ equiaxed delta-ferrite distributed on the prior austenite grain boundaries, as illustrated in Fig. 6 .

Transmission electron micrographs of the as-tempered specimens are shown in Fig. 7. Steel $\mathrm{C}$ was characterized by the coarse precipitates formed at martensite/delta-ferrite phase boundaries (Fig. 7(D)), although little difference could be observed within the tempered-martensite phase among steels $\mathrm{A}, \mathrm{B}$ and C (Figs. 7(A) to 7(C)). Further investigation revealed that these coarse phase-boundary precipitates formed during slow cooling after austenitization. Examining carbon extraction replica revealed that the precipitates are film-like $\mathrm{M}_{23} \mathrm{C}_{6}$ type carbides, which surround delta-ferrites, as shown in Fig. 8. The formation of these precipitates could be explained by the fact that when delta-ferrite exists, the ferrite formers such as $\mathrm{Mo}, \mathrm{W}, \mathrm{V}$ and $\mathrm{Cr}$ would tend to become richer in the delta-ferrite phase, while the austenite formers such as $\mathrm{C}, \mathrm{N}$ would tend to diffuse away from the delta-ferrite and become richer in the vicinity of the delta-ferrite phase boundaries. ${ }^{11}$ Thus, the prior austenite (martensite after transformation)/ delta-ferrite interfaces would become preferred formation and growth sites of the precipitates during slow cooling.

After crept at high temperatures, the vicinity of delta-ferrites shows faster recovery than other parts of martensite phase, although the delta-ferrite phase itself shows little change, Fig. 9 shows such an example. This tendency becomes more distinct at longer rupture time.

\subsection{Extracts}

The amounts of extracted residues are shown in Fig. 10. In the as-tempered condition, the amount of precipitates increases with chromium content, and the increment from steel $B$ to steel $C$ is more than that from steel A to steel B. However, the difference in the amount of precipitates among the three becomes smaller with the increase in creep rupture time.
The type of precipitates identified by X-ray diffraction of the extracted residues are presented in Table 2. In the as-normalized condition, only NbC carbides are detected in steels $\mathbf{A}$ and $\mathbf{B}$. In contrast, a considerable amount of $\mathrm{M}_{23} \mathrm{C}_{6}$ carbides, apparently corresponding with the film-like carbides around delta-ferrite, coexists with $\mathrm{NbC}$ in steel $\mathrm{C}$. In the as-tempered as well as the creep ruptured specimens, the main precipitate is $\mathrm{M}_{23} \mathrm{C}_{6}$ for all the three steels, accompanied by a small amount of $\mathrm{Cr}_{2}(\mathrm{C}, \mathrm{N})$ (orthorhombic) and NbG. In the specimens creep ruptured at times longer than about $500 \mathrm{~h}$, Laves phase $\left(\mathrm{Fe}_{2}(\mathrm{Mo}, \mathrm{W})\right)$ is also detected. Although precipitate types are the same for the three steels, the fraction of the $\mathrm{Cr}_{2}(\mathrm{C}, \mathrm{N})$ in the extracts varies with chromium content, as shown in Fig. 11. For the heights of the main peaks of $\mathrm{M}_{23} \mathrm{C}_{6}$ of the three steels are almost the same here, the increase in the heights of the main peak of $\mathrm{Cr}_{2}(\mathrm{C}, \mathrm{N})$ with chromium content implies that

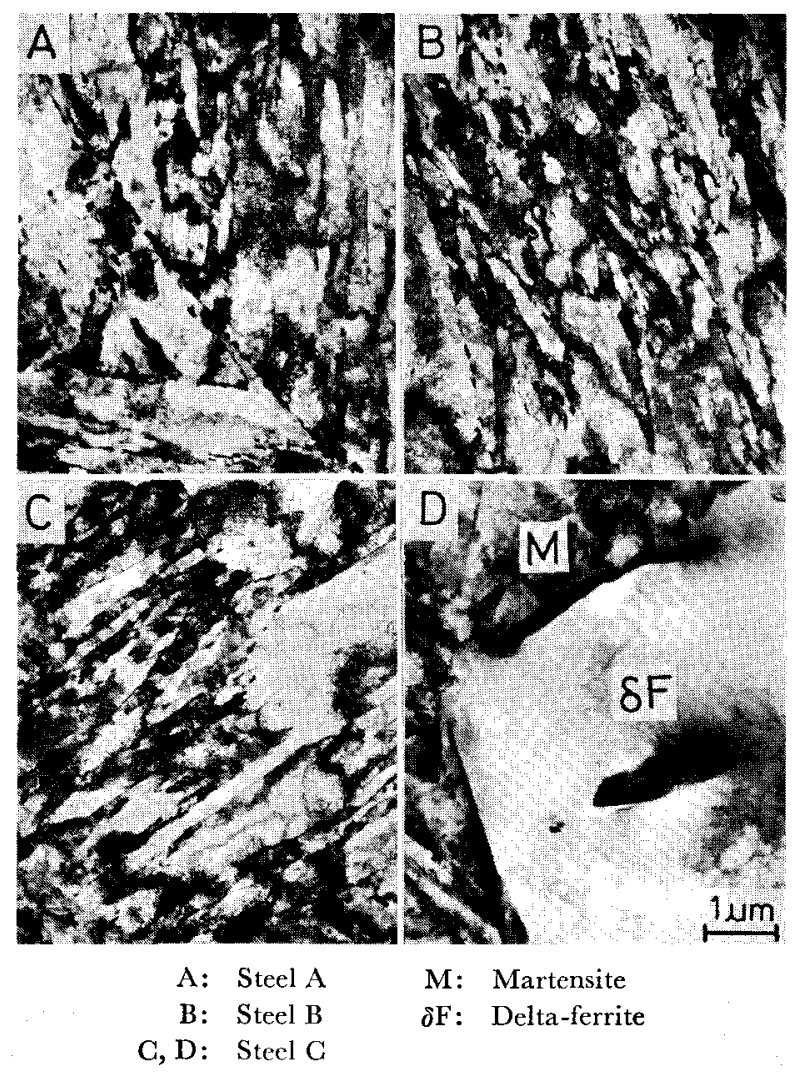

Fig. 7. Transmission electron micrographs for the specimens in the as-tempered condition.

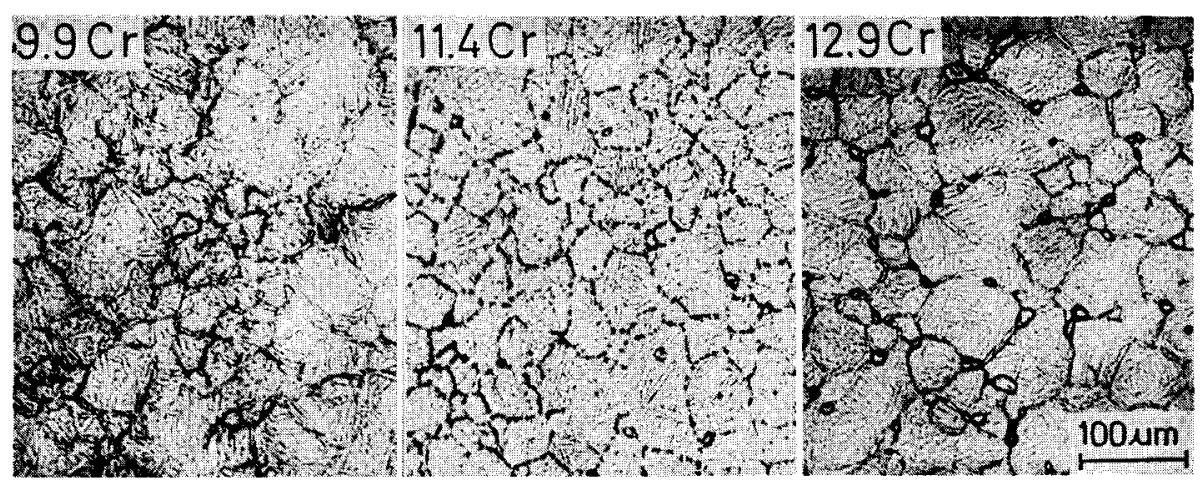

Fig. 6.

Optical microstructures of the specimens in the as-normalized condition. 

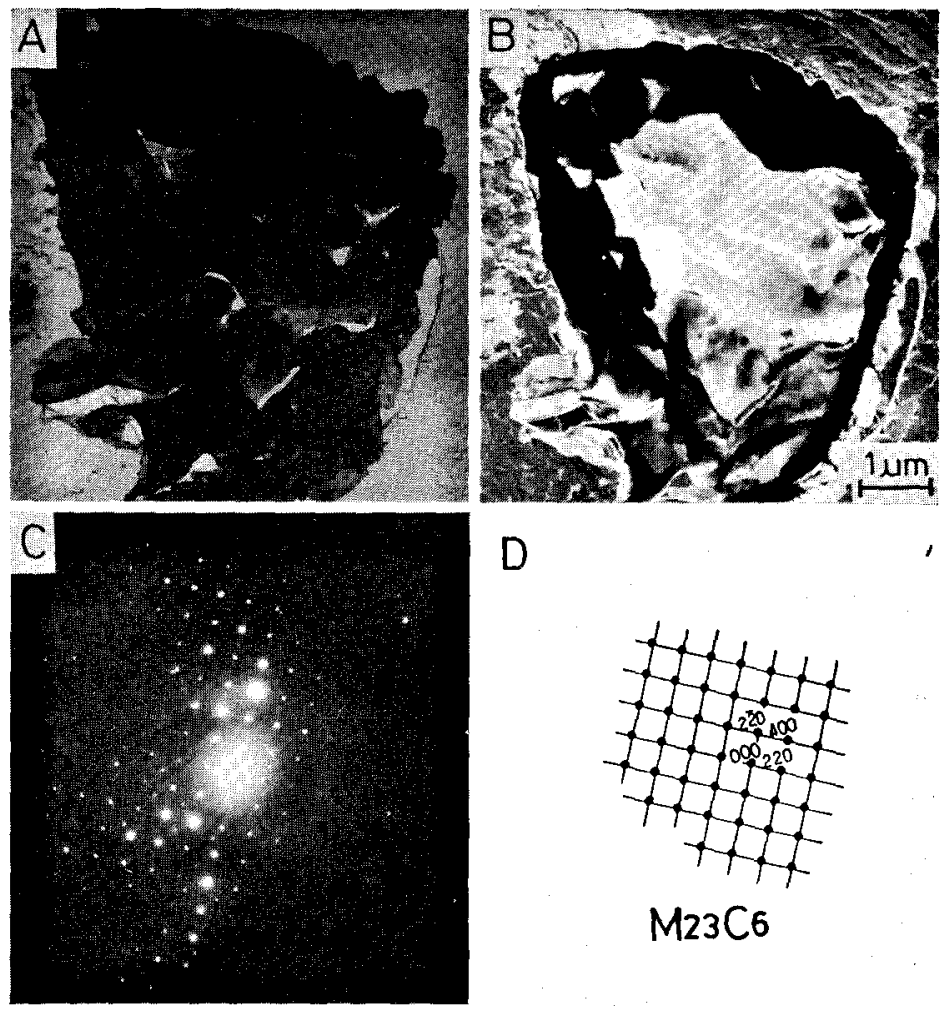

D

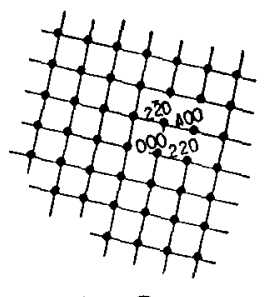

$\mathrm{M} 23 \mathrm{C} 6$

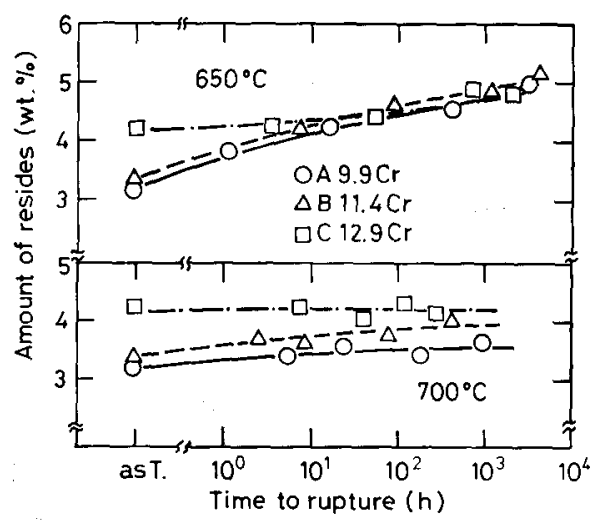

Fig. 10.

Change in the amounts of extracted residues with chromium content and rupture time.

A: Bright fieid image

B: Dark field image of the 400 spot

G: Diffraction pattern

D: Key diagram

Fig. 8. Transmission electron micrographs of extraction carbon replica for steel $\mathrm{C}$ in the as-normalized condition.

\begin{abstract}
M: Martensite
$\delta$ F: Delta-ferrite

Fig. 9.

Transmission electron micrographs of the specimens creep ruptured at $700^{\circ} \mathrm{C}, 10 \mathrm{~kg} / \mathrm{mm}^{2}$, showing the faster recovery in the vicinity of delta-ferrites.
\end{abstract}

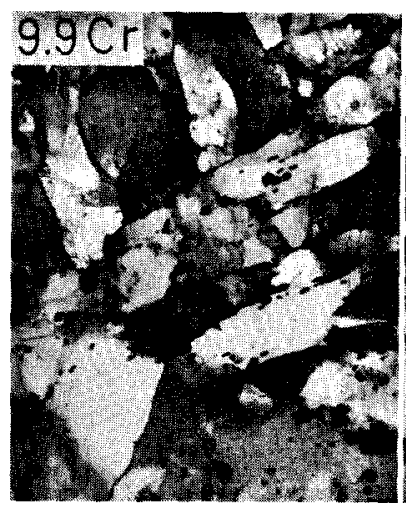

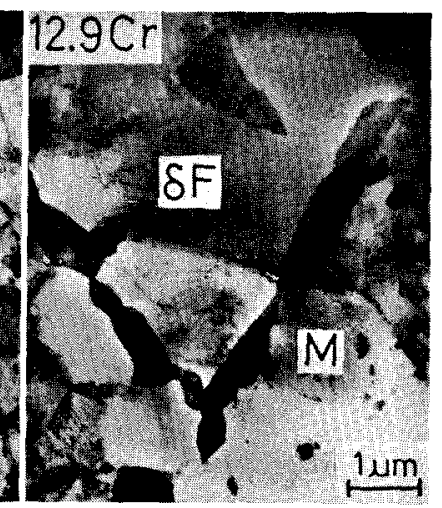

the fraction of $\mathrm{Cr}_{2}(\mathrm{C}, \mathrm{N})$ in extracts increases with chromium content for the specimens creep ruptured at the same stress level. Allowing for that the rupture times are different at the same test stress for the three steels and the precipitation usually depends on the exposure time at elevated temperatures, the relative amount of $\mathrm{Cr}_{2}(\mathrm{C}, \mathrm{N})$ to $\mathrm{M}_{23} \mathrm{C}_{6}$, which is indicated qualitatively by the main peak height ratio of the two, is plotted in Fig. 12 as a function of creep rupture time. It can be seen that the above mentioned conclusion still applies for the same exposure time.

\section{Discussion}

\subsection{The Solution Hardening Effect of Chromium}

The partition of chromium between in the matrix and in precipitates is shown in Fig. 13. Here, the amounts of precipitated chromium are derived ex- perimentally from the weight percentages of residues and the results of composition analysis of the residues by EDXA. On the other hand, the amounts of chromium in solution are calculated from the amounts of precipitated chromium and the total amounts of chromium contained in steels. As Fig. 13 shows, only a small part of the chromium contained in steels exists in precipitates, with the main part existing in the matrix. Moreover, the increase in the chromium contents brings about increases both in the amount of dissolved chromium and in the amount of precipitated chromium, although the increase in the former are much greater than that in the latter, i.e., the increase in the chromium content results in mainly an increase in the amounts of dissolved chromium.

The solution hardening effect of chromium in steels is supposed to be small because the atom size of chromium is almost the same as that of iron, but chro- 
ISIJ International, Vol. 29 (1989), No. 8

Table 2. Precipitates identified by X-ray diffraction.

\begin{tabular}{|c|c|c|c|c|c|c|}
\hline Steels & As-normalized & As-tempered & $650^{\circ} \mathrm{C}, 20 \mathrm{kgf} / \mathrm{mm}^{2}$ & $650^{\circ} \mathrm{C}, 16 \mathrm{kgf} / \mathrm{mm}^{2}$ & $700^{\circ} \mathrm{C}, 12 \mathrm{kgf} / \mathrm{mm}^{2}$ & $700^{\circ} \mathrm{C}, 10 \mathrm{kgf} / \mathrm{mm}^{2}$ \\
\hline A & $\mathrm{NbC}$ & $\begin{array}{l}\mathrm{M}_{23} \mathrm{C}_{6} \\
\mathrm{Cr}_{2}(\mathrm{C}, \mathrm{N})^{*} \\
\mathrm{NbC}^{* *}\end{array}$ & $\begin{array}{l}\mathrm{M}_{23} \mathrm{C}_{6} \\
\mathrm{Cr}_{2}(\mathrm{C}, \mathrm{N})^{*} \\
\mathrm{NbG}^{* *} \\
(16.0)\end{array}$ & $\begin{array}{l}\mathrm{M}_{23} \mathrm{C}_{6} \\
\mathrm{Cr}_{\mathrm{c}}(\mathrm{C}, \mathrm{N})^{*} \\
\text { Laves** }^{* *} \\
\mathrm{NbC}^{* *} \\
(435)\end{array}$ & $\begin{array}{l}\mathrm{M}_{23} \mathrm{C}_{6} \\
\mathrm{Cr}_{\varepsilon}(\mathrm{C}, \mathrm{N})^{*} \\
\mathrm{NbC}^{* *} \\
(23.9)\end{array}$ & $\begin{array}{l}\mathrm{M}_{23} \mathrm{C}_{6} \\
\mathrm{Cr}_{2}(\mathrm{C}, \mathrm{N})^{*} \\
\mathrm{NbC}^{* *} \\
(183)\end{array}$ \\
\hline B & $\mathrm{NbC}$ & $\begin{array}{l}\mathrm{M}_{23} \mathrm{C}_{6} \\
\mathrm{Cr}_{2}(\mathrm{C}, \mathrm{N})^{*} \\
\mathrm{NbC}^{* *}\end{array}$ & $\begin{array}{l}\mathrm{M}_{23} \mathrm{C}_{6} \\
\mathrm{Cr}_{2}(\mathrm{C}, \mathrm{N})^{*} \\
\mathrm{NbC}^{* *} \\
(90.5)\end{array}$ & $\begin{array}{l}\mathrm{M}_{23} \mathrm{C}_{6} \\
\mathrm{Cr}_{2}(\mathrm{C}, \mathrm{N})^{*} \\
\text { Laves* } \\
\text { NbC* } \\
(1200)\end{array}$ & $\begin{array}{l}\mathrm{M}_{23} \mathrm{C}_{6} \\
\mathrm{Cr}_{\mathrm{2}}(\mathrm{C}, \mathrm{N})^{*} \\
\mathrm{NbC}^{* *} \\
(78.4)\end{array}$ & $\begin{array}{l}\mathrm{M}_{23} \mathrm{C}_{6} \\
\mathrm{Cr}_{2}(\mathrm{C}, \mathrm{N})^{*} \\
\mathrm{Laves}^{* *} \\
\mathrm{NbC}^{* *} \\
(399)\end{array}$ \\
\hline $\mathrm{C}$ & $\begin{array}{l}\mathrm{M}_{23} \mathrm{C}_{6} \\
\mathrm{NbC}^{*}\end{array}$ & $\begin{array}{l}\mathrm{M}_{23} \mathrm{C}_{6} \\
\mathrm{Cr}_{2}(\mathrm{C}, \mathrm{N})^{*} \\
\mathrm{NbC}^{* *}\end{array}$ & $\begin{array}{l}\mathrm{M}_{23} \mathrm{C}_{6} \\
\mathrm{Cr}_{2}(\mathrm{C}, \mathrm{N})^{*} \\
\mathrm{NbG}^{* *} \\
(55.1)\end{array}$ & $\begin{array}{l}\mathrm{M}_{23} \mathrm{C}_{6} \\
\mathrm{Cr}_{2}(\mathrm{C}, \mathrm{N})^{*} \\
\mathrm{Laves}^{*} \\
\mathrm{NbC}^{* *} \\
(720)\end{array}$ & $\begin{array}{l}\mathrm{M}_{23} \mathrm{C}_{6} \\
\mathrm{Cr}_{\mathrm{E}}(\mathrm{C}, \mathrm{N})^{*} \\
\mathrm{NbC}^{* *} \\
(41.1)\end{array}$ & $\begin{array}{l}\mathrm{M}_{23} \mathrm{C}_{6} \\
\mathrm{Cr}_{2}(\mathrm{C}, \mathrm{N})^{*} \\
\mathrm{NbC}^{* * *} \\
(122)\end{array}$ \\
\hline
\end{tabular}

Not marked: Strong, *: Medium, **: Weak, ( ): Rupture time

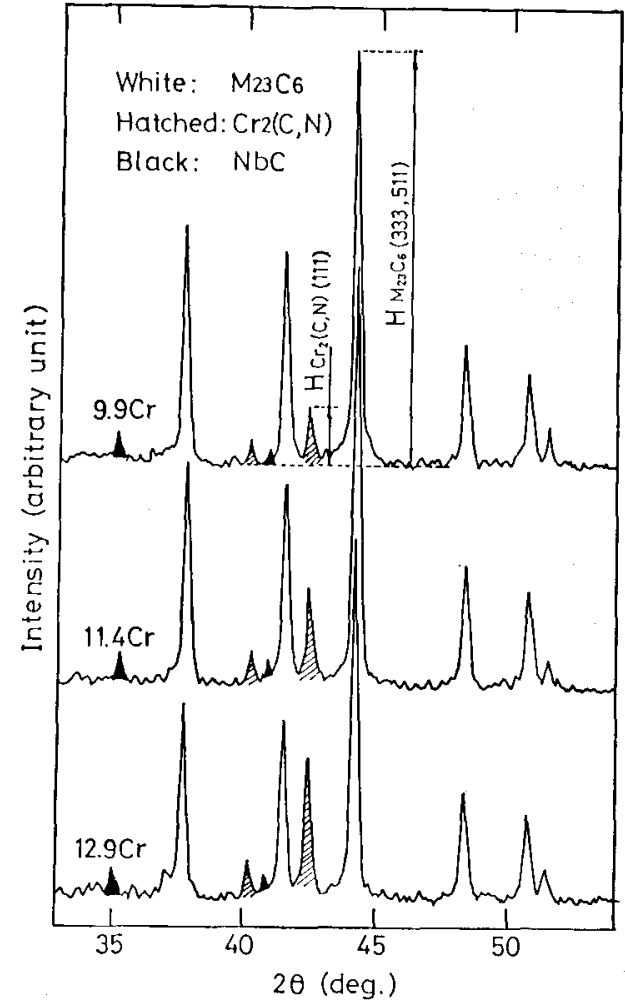

Fig. 11. X-ray diffraction chart of the residues extracted from the specimens crept at $650^{\circ} \mathrm{C}, 12 \mathrm{kgf} / \mathrm{mm}^{2}$.

mium addition does enhances the room temperature tensile strength of steels by solution hardening. ${ }^{12,13)}$ Furthermore, Monma et al. ${ }^{14)}$ have clarified that when $\mathrm{C}$ and $\mathrm{N}$ are almost completely removed by wethydrogen treatment of some low-carbon, low-nitrogen steels, hardness at 400 to $600^{\circ} \mathrm{C}$ increases considerably with chromium content, which indicates strongly that chromium also have an important solution hardening effect at elevated temperatures. Therefore, it could be expected that the marked increase in the amounts of dissolved chromium would be effective on the improving of the elevated temperature strength.

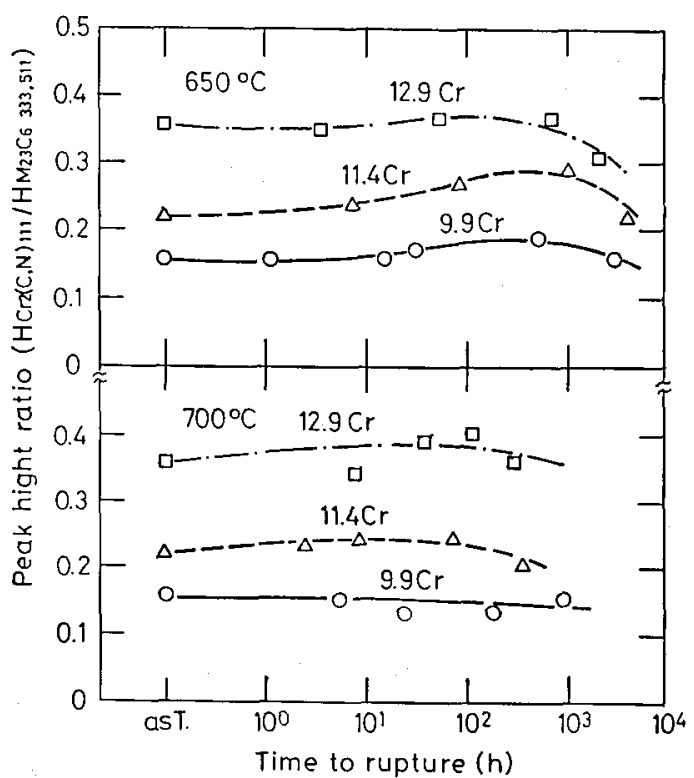

Fig. 12. Change in main peak height ratios of $\mathrm{M}_{23} \mathrm{C}_{6}$ to $\mathrm{Cr}_{2}(\mathrm{C}, \mathrm{N})$ with rupture time.

\subsection{The Precipitation Hardening Effect Related to Chro- mium}

Together with the increase in chromium content, the increase in the amount of $\mathrm{Cr}_{2}(\mathrm{C}, \mathrm{N})$ type carbides has been confirmed by X-ray diffraction (Figs. II and 12). This kind of precipitates is usually needle-like or rod-like and very small in dimensions, thus has an important precipitation strengthening effect. In this study, there exist some rod-like carbides in the astempered as well as crept specimens, as shown in Fig. 14. The density of these rod-like precipitates increases with chromium content. Though direct identification of these precipitates by electron diffraction failed because of their very small dimensions, from the facts that only chromium is included in the rodlike precipitates and the density of them in the microstructures increases simultaneously with the X-ray diffraction intensity of $\mathrm{Cr}_{2}(\mathrm{C}, \mathrm{N})$, it is deduced that 


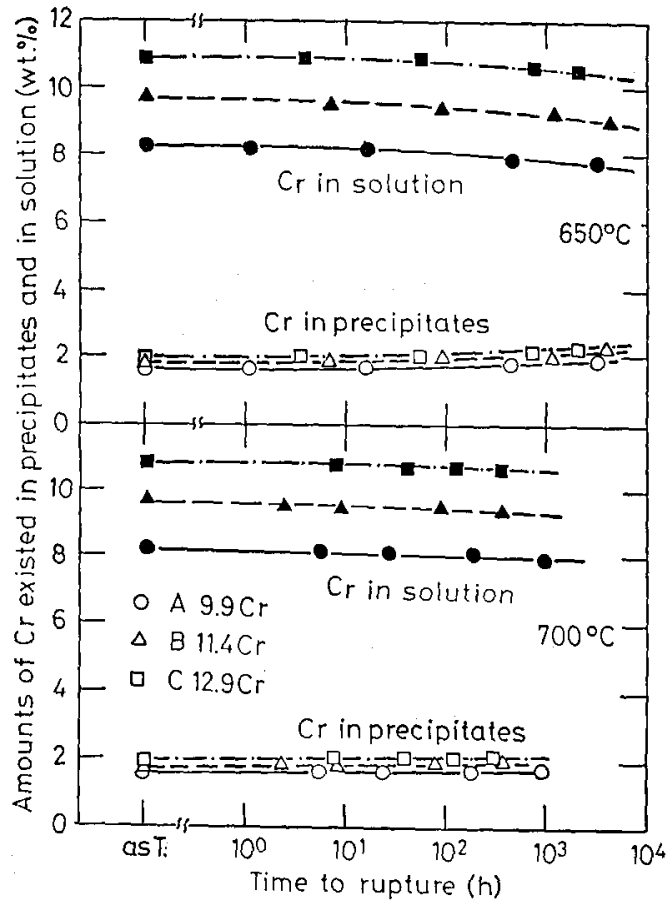

Fig. 13. Partition of chromium between in precipitates and in solution.

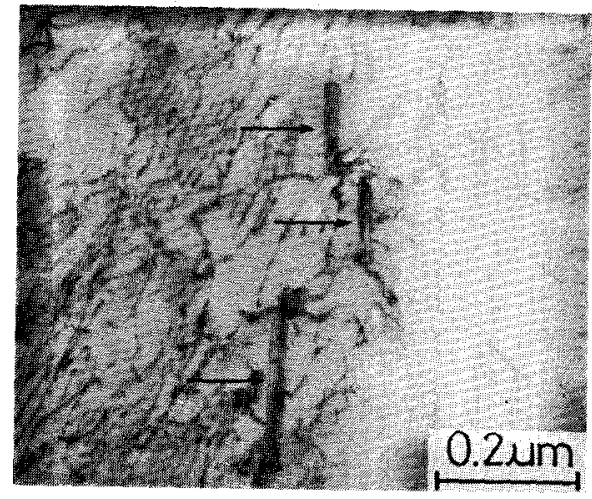

Fig. 14. Transmission electron micrographs of steel B in the as-tempered condition, showing the precipitation of the rod-like carbides.

the rod-like precipitates are $\mathrm{Cr}_{2}(\mathrm{C}, \mathrm{N})$ type carbides. These fine rod-like carbides mainly precipitate within the martensite lathes and show an effect of pinning up dislocations (Fig. 14). Thus, the increase in these fine rod-like $\mathrm{Cr}_{2}(\mathrm{C}, \mathrm{N})$ with chromium content would be an important factor that enhances creep rupture strength.

\subsection{The Effect of Delta-ferrite}

The above discussion indicates that the increase in chromium content will increase the solution and precipitation hardening and thus enhances creep rupture strength, but these can not explain why steel $\mathrm{C}$ shows a lower creep rupture strength than the others, although it contains more chromium. This is related to the existence of delta-ferrite in steel $\mathrm{C}$, as shown in Fig. 6.

It has been known that delta-ferrite is detrimental to tensile and fatigue properties, ${ }^{15,16)}$ especially when it exists in stringers, because delta-ferrites form weaker areas which make deformation and failure easier. As for elevated temperature strength, E. A. Loria ${ }^{17)}$ reported that when exposed to 538 or $593^{\circ} \mathrm{C}$ for up to $1000 \mathrm{~h}$, less than $18 \%$ delta-ferrite had no apparent effect on the creep rupture strength for the specimens with the gauge length direction parallel to the longitudinal direction of the forged ingot, although over $8 \%$ delta-ferrite did lower the transverse rupture strength at $538^{\circ} \mathrm{C}$.

In this study, steels $C$ and $A$ show almost the same strength level in room-temperature tensile test as well as in the short-term creep rupture test, despite that steel $\mathrm{C}$ contains about $2 \%$ delta-ferrite. This result indicates that small amount of delta-ferrite has no apparent effect on strengths in such conditions, and is in accordance with Loria's. However, on long-term creep rupture test, the faster recovery of the vicinity of delta-ferrite, possibly resulted from the consumption of such alloying elements as Mo, W, and Cr by the formation of the coarse $\mathrm{M}_{23} \mathrm{C}_{6}$, is in good accordance with the drastic decrease in long-term creep rupture strength in steel $\mathrm{C}$. The fact indicates strongly that delta-ferrite is detrimental to the long-term creep rupture strength even if the amount is only $2 \%$. Although this result is different from Loria's, it can be explained without contradiction when the experimental procedures and the test conditions used in this study and in Loria's study are taken into consideration. That is, Loria introduced delta-ferrite by increasing austenitizing temperature, which usually enhances elevated temperature strength by increasing prior austenite grain size and reducing the amount of undissolved carbides. Thus, the detrimental effect of delta-ferrite may partly be compensated by these factors. Furthermore, Loria carried out creep rupture test at 538 and $593^{\circ} \mathrm{C}$, much lower than the test temperatures of 650 and $700^{\circ} \mathrm{C}$ used in the current study. Noticing that the creep rupture strength of steel $\mathrm{C}$ decreases in a shorter time at $700^{\circ} \mathrm{C}$ than at $650^{\circ} \mathrm{C}$ (Fig. 1), It could be concluded that the detrimental effect of delta-ferrite accelerates with increasing test temperature. Therefore, at lower temperatures, longer time is necessary for the effect to become apparent.

\section{Summary}

The effect of chromium content in the range of 10 to $13 \%$ on creep rupture strength as well as toughness has been investigated. The results are as follows:

(1) Creep rupture strength changes with chromium content, and shows a maximum at around $11.5 \%$ chromium. On the other hand, Charpy impact energy decreases when chromium content increases.

(2) The increase in chromium content results in both increase in the amount of chromium in the matrix and the amount of the $\mathrm{Cr}_{2}(\mathrm{C}, \mathrm{N})$ type carbides. Both of the changes are believed to be the positive factors to elevated temperature strength as well as room-temperature strength.

(3) When chromium content is increased to $13 \%$, about $2 \%$ delta-ferrite formed. The formation of 
delta-ferrite and the related film-like carbides is detrimental to the elevated temperature strength, especially on the long-term side, even if it is in a small amount.

\section{Acknowledgement}

The authors wish to thank Associate Professor K. Shibata of The University of Tokyo for his valuable advice and discussion during the course of this work.

\section{REFERENCES}

1) S. Ota, Y. Fujiwara and H. Uchida: The 123rd Comm. (Heat-Resisting Metals and Alloys), Japan Soc. Promotion of Sci. (JSPS), Rep. No. 1 (Mar., 1985), 41.

2) K. Asakura and T. Fujita: The 123rd Comm. (HeatResisting Metals and Alloys), Japan Soc. Promotion of Sci. (JSPS), Rep. No. 3 (Nov., 1985), 281.

3) E. W. Colbeck and J. R. Rait: Iron Steel Inst. Spec. Rep. No. 43, (1952), 107.

4) X. Y. Liu, T. Fujita, A. Hizume and S. Kinoshita: Tetsuto-Hagané, 71 (1985), S1565; Trans. Iron Steel Inst. Jpn., 26 (1986), B117.
5) R. Franks: Trans. Am. Soc. Met, 35 (1945), 616.

6) H. E. McGannon: The Making, Shaping and Treating of Steel, 9th ed., US Steel Corp., Pittsburgh, (1971), 1196.

7) H. E. McGannon: The Making, Shaping and Treating of Steel, 9th ed., US Steel Corp., Pittsburgh, (1971), 1168.

8) K. J. Irvine, D. J. Crowe and F. B. Pickering: J. Iron Steel Inst., 195 (1960), 386.

9) T. Fujita, T. Sasakura and Y. Takeno: Tetsu-to-Hagané, 49 (1963), 597.

10) J. Z. Briggs and T. D. Parker: The Super $12 \%$ Cr Steels, Climax Molybdenum Co., Michigan, (1982), 99.

11) I. Park and T. Fujita: Tetsu-to-Hagané, 67 (1981), S1146; Trans. Iron Steel Inst. Jpn., 22 (1982), B102.

12) G. A. Redfern and C. M. Sellars: J. Iron Steel Inst., 208 (1970), 576 .

13) B. Homes and D. J. Dyson: J. Iron Steel Inst., 208 (1970), 469.

14) K. Monma, H. Suto, K. Sotome and T. Nemoto: J. Jpn. Inst. Met., 29 (1965), $19 \mathrm{I}$.

15) G. E. Dieter: Trans. Am. Soc. Met., 50 (1958), 722.

16) M. L. Shaw, T. B. Cox and W. C. Leslie: J. Maler. Energy Syst., 8 (1987), 347.

17) E. A. Loria: Trans. Am. Soc. Met., 54 (1961), 31. 